\title{
Transfiguration of Saving and Spending Habits of College Students Ascribed to Internet Banking
}

\author{
Sharmila V.
}

\begin{abstract}
Transfiguration of saving and spending habit of college students ascribed to internet banking address the question of Why, Where and How the college students spend and save their money. The extension of marketing and multiplication of brand as influenced the adults with increase in spending power. The objective of study is to analysis the various mode of saving habit, spending pattern and to identify the changes in saving and spending status due to internet banking.The survey is conducted among the sample size of 50 respondents by structured questionnaire. The respondents are college students under various educational qualification in particular to under graduate, post graduate and professional course. The questionnaire partitioned into three parts namely respondents profile, saving and spending patterns and its status. Each responses are entered and findings are analyzed using various statistical tool such as EXCEL and SPSS for charts and graphical representation. The findings revealed that majority of college students prefer bank account for the purpose of savings and they are using online banking app for the day to day transactions spent on various streams which has been ranked in the following study. The transfiguration in saving and spending status after usage of internet banking by college students is clearly analyzed in the study and stated as saving is lesser than spending..
\end{abstract}

Keywords: Saving, Spending, Habits, Internet banking and College students..

\section{INTRODUCTION}

G etting richer is not income, it is all about how we spend it. Spending less than earnings and saving for the future is the most essential habit that need to be built in every individual at the initial stage of growing up through the saving pocket money in piggy banks which creates the saving habit and financial management strategies for all the members of society. The study as aimed to analysis the saving and spending habit among college students and transfiguration that is change in their saving and spending status due to internet banking. Internet banking is determined as e-commerce platform which allows the students to do online shopping, online booking, mobile recharges and online entertainments.

\section{OBJECTIVES OF THE STUDY}

- To figure out the spending pattern among college students. - To analysis the various mode of savings of college

Revised Manuscript Received on December 05, 2019.

* Correspondence Author

Sharmila V.*, Anna Adharash College for Women, Anna Nagar, Chennai, India.Email: sharmilavenkat1997@gmail.com students.

- To identify changes saving and spending status influenced by internet banking.

\section{METHODOLOGY OF STUDY}

Source of Data: The present study is based on primary data which was collected using questionnaire method.

Sample Size: Fifty two college students from various educational qualification such as under graduate, post graduate and professional course within Chennai city.

Data Collection: The data was collected using questionnaire in colleges. Both open ended and closed ended questions.

Statistical Tools: Simple Percentage method is used to analyze the data through SPSS and Microsoft Excel.

\section{LIMITATION OF THE STUDY}

- The study is purely based on the view of 52 respondent only.

- The area of the study is confined only in Chennai city.

- In depth analysis could not be carried out because of shorter time period.

\section{REVIEW OF LITERATURE}

P. Jeevitha and R. Kanya Priya (2019) ${ }^{1}$ examined the saving and spending habit of college students with referenceto Coimbatore city.The findings of study declared that maximum no. of students have saved less than spent but spending fields were different. The respondents regularly preferred saving bank account as their saving avenue.

Samantha Villanueva $(2017)^{2}$ analyzed the factor affecting spending and saving habits of college students which showcased the significant difference in spending pattern among both male and female whose income is only through pocket money from parents and relatives. The study concluded student spend maximum amount towards fast food, movie, transportation and balance of pocket money at the end of month in saving for the purpose of future benefit. Mebin John Mathews $(2017)^{3}$ analyzed the spending and saving pattern of college students in Idukki district. Majority of students are not having habit of saving and only few students are interested to earn to meet their own expenses. The students are need to be aware about saving and invest them in productive channels.

Jeni Theresa. C. Bona $(2017)^{4}$ studied spending behavior among college students. The students were not anxious to work in order to earn money to meet their day to day expenditure. 
Only minority of students involved in job to earn money and help to reduce the load of parents. Every few respondents receive scholarship for educational expenses.

Shilpa Chhabra (2016) ${ }^{5}$ evaluated saving and spending trends among youth an empirical study on Sirsa district. The study figured out significance difference exist between male and female by different spending behaviour. The study aimed to create an awareness to cultivate habit of rational spending and students should move towards savings and investment.

\section{FINDINGS, ANALYSIS AND INTERPRETATION}

Table - I: Demographic Profile of the Respondents

\begin{tabular}{|c|c|c|}
\hline ON THE BASIS OF & CLASSIFICATION & $\begin{array}{c}\text { PERCENTA } \\
\text { GE }\end{array}$ \\
\hline \multirow{2}{*}{ GENDER } & Male & $40 \%$ \\
\hline & Female & $60 \%$ \\
\hline \multirow{3}{*}{$\begin{array}{l}\text { EDUDATIONAL } \\
\text { QUALIFICATION }\end{array}$} & Under graduate & $56 \%$ \\
\hline & Post graduate & $34 \%$ \\
\hline & Professional course & $10 \%$ \\
\hline \multirow{4}{*}{ SOURCE OF INCOME } & Pocket money & $55 \%$ \\
\hline & Scholarship & Nil \\
\hline & Parttime job & $10 \%$ \\
\hline & Others & $35 \%$ \\
\hline \multirow{4}{*}{ EARNINGS PER MONTH } & Less than 2000 & $48 \%$ \\
\hline & $2001-3000$ & $17 \%$ \\
\hline & $3001-4000$ & $7 \%$ \\
\hline & More than 4000 & $27 \%$ \\
\hline \multirow{4}{*}{ SAVING PER MONTH } & Less than 500 & $49 \%$ \\
\hline & $501-1000$ & $25 \%$ \\
\hline & $1001-1500$ & $12 \%$ \\
\hline & More than 1500 & $14 \%$ \\
\hline
\end{tabular}

The majority of the 60 percentage of respondents are female and 40 percentage of the respondents are male. The respondents are college going students under various qualification listed as 56\% are under graduate students, 34\% are post graduate students and $10 \%$ are professional course students. Source of income of college students are mostly received as pocket money dependent on their parents. Both earnings and spending are the least amount Rs. 2000 and Rs. 500 .

\section{MAJOR FINDINGS}

a). Objective 1: To Figure The Spending Pattern Among College Students

\begin{tabular}{|c|c|}
\hline PAYMENT MODE & PERCENTAGE \\
\hline Cash & 58 \\
\hline Card payment & 27 \\
\hline Online payment & 15 \\
\hline TOTAL & 100 \\
\hline & \\
\hline & \\
\hline & \\
\hline
\end{tabular}

b.) Objective 2: To Analysis Modes Of Saving Among College Students

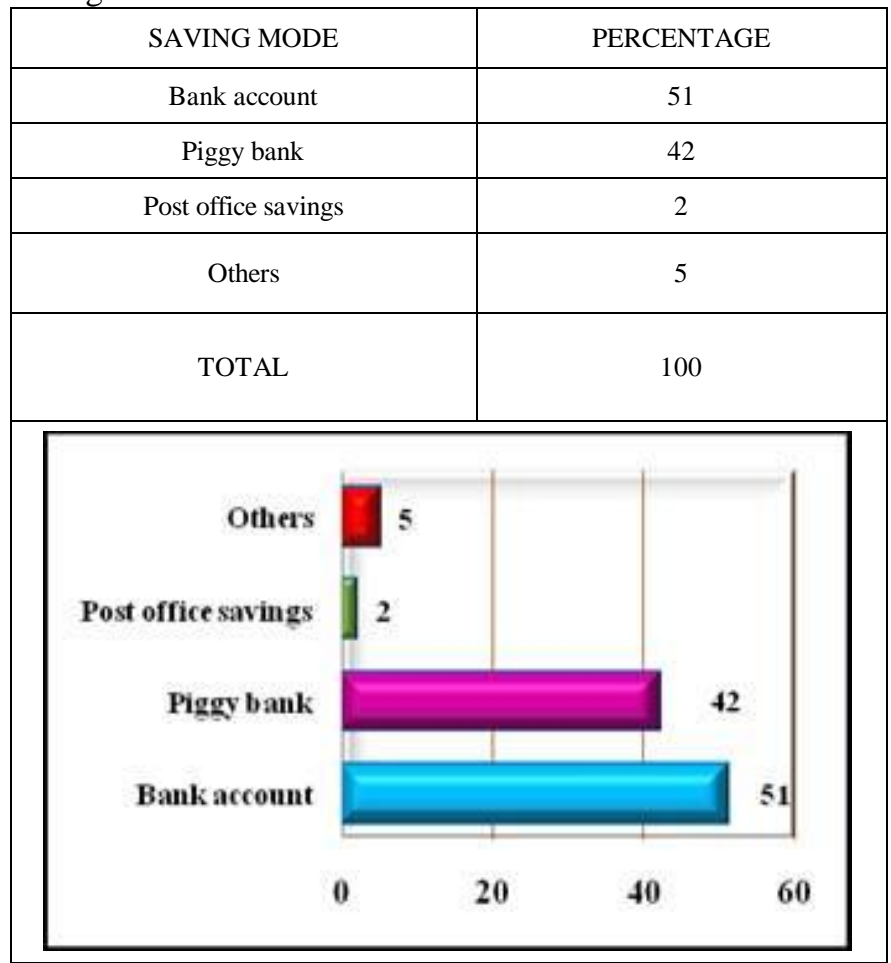

Published By:

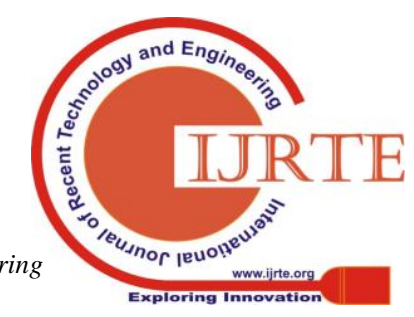


c). Objective 3: To Identify Saving And Spending Status -Internet Banking

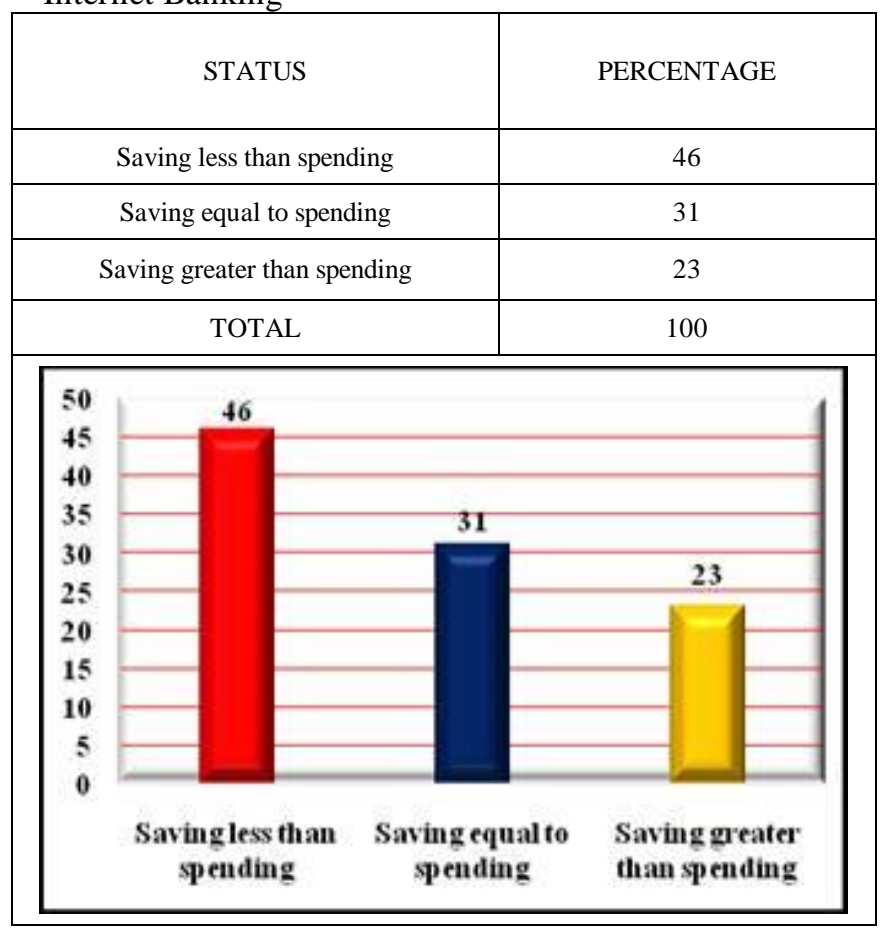

\section{OTHER FINDINGS}

From the following areas where do you spend the most?

\begin{tabular}{|c|c|c|}
\hline AREA OF SPENDINGS & $\begin{array}{c}\text { NO. OF. RESPONSES } \\
\text { (WEIGHTED SCORE) }\end{array}$ & RANK \\
\hline Shopping & 27 & 1 \\
\hline Entertainment & 23 & 2 \\
\hline Transport & 22 & 3 \\
\hline Mobile Recharge & 12 & 4 \\
\hline Studies & 9 & 5 \\
\hline Fitness & 6 & 6 \\
\hline Beauty care & 5 & 7 \\
\hline
\end{tabular}

What is your purpose of the savings?

\begin{tabular}{|c|c|}
\hline PURPOSE OF SAVINGS & PERCENTAGE \\
\hline Habit & 14 \\
\hline Higher studies & 9 \\
\hline Future needs & 30 \\
\hline Emergency purpose & 47 \\
\hline TOTAL & 100 \\
\hline
\end{tabular}

\section{MAJORITY OF FINDINGS}

- The majority of $83 \%$ students have the habit of saving.

- The majority of $67 \%$ uses online banking app.

- The majority of $58 \%$ prefers cash payment.

- The majority of 51\% prefers bank account as the mode of saving.

- The transfiguration as made in status of spending and saving of students due to internet banking found with majority of $46 \%$ as saving is lesser than spending.
- The spending areas is ranked and listed in the order of majority to minority such as shopping, entertainment, transport, recharge, studies, fitness and beauty care.

- The majority of $47 \%$ of students save for emergency purpose.

- The majority of $83 \%$ students have the habit of saving.

- The majority of $67 \%$ uses online banking app.

\section{CONCLUSION}

The study has conducted on "the transfiguration of saving and spending habits of college students ascribed to internet banking" was undertaken to know the saving and spending of college students. The study concludes that saving and spending status of college students has savings is lesser than spending after the usage internet banking due to easy availability of online services. The study suggests that there is need to create an awareness among college students on their saving and spending avenues and financial management strategies which essential for the development of individual and to an economy growth.

\section{REFERENCES}

1. P. Jeevitha and R. Kanya Priya - A study on saving and spending habits of college students with reference to Coimbatore city. Volume 6 I Issue1, Jan - March 2019.ISSN 2348 -1269, PRINT ISSN 2349-5138.

2. Mebin John Mathews - An analysis on spending and saving pattern of college students in Idukki district. International Journal of Management (IJM)Volume 8, Issue 3, May-June 2017, pp.199-203.

3. Samantha Villanueva - An analysis of factor affecting the spending and saving habits of college students 2016 .

4. Jeni Theresa .C - Bona Spending behaviour among college students, Sci.Int.(Lahore), 29(4),749-753, ISSN 1013-5316.

5. Shilpa Chhabra - Saving and spending trends among youth an empirical study on Sirsa district 2016.

\section{AUTHOR PROFILE}

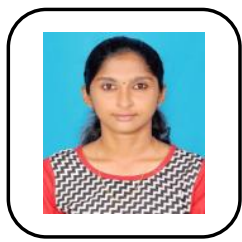

Sharmila .V, M.Com, M.Phil. (On going) Research Scholar of Anna Adarsh College for Women, Anna Nagar, Chennai-40. Research area is focused on banking technology. She is also actively participating in various national and international conferences. Constantly publishing the articles in various leading journals in the filed of commerce. 